Issued by Sandia National Laboratories, operated for the United States Department of Energy by Sandia Corporation.

NOTICE: This report was prepared as an account of work sponsored by an agency of the United States Government. Neither the United States Government, nor any agency thereof, nor any of their employees, nor any of their contractors, subcontractors, or their employees, make any warranty, express or implied, or assume any legal liability or responsibility for the accuracy, completeness, or usefulness of any information, apparatus, product, or process disclosed, or represent that its use would not infringe privately owned rights. Reference herein to any specific commercial product, process, or service by trade name, trademark, manufacturer, or otherwise, does not necessarily constitute or imply its endorsement, recommendation, or favoring by the United States Government, any agency thereof, or any of their contractors or subcontractors. The views and opinions expressed herein do not necessarily state or reflect those of the United States Government, any agency thereof, or any of their contractors.

Printed in the United States of America. This report has been reproduced directly from the best available copy.

Available to DOE and DOE contractors from

Office of Scientific and Technical Information

P.O. Box 62

Oak Ridge, TN 37831

Prices available from (703) 605-6000

Web site: $h t t p: / / w w w . n t i s . g o v / o r d e r i n g . h t m$

Available to the public from

National Technical Information Service

U.S. Department of Commerce

5285 Port Royal Rd

Springfield, VA 22161

NTIS price codes

Printed copy: A03

Microfiche copy: A01

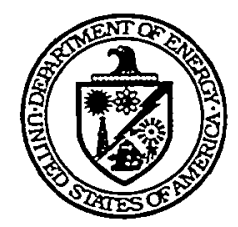




\section{DISCLAIMER}

Portions of this document may be illegible in electronic image products. Images are produced from the best available original document. 


\title{
Weld Properties of a Free Machining Stainless Steel
}

\author{
J. A. Brooks \\ Engineered Materials Department \\ S. H. Goods \\ Materials Mechanics Department \\ C. V. Robino \\ Materials Joining Department \\ Sandia National Laboratories/California
}

\begin{abstract}
The all weld metal tensile properties from gas tungsten arc and electron beam welds in free machining austenitic stainless steels have been determined. Ten heats with sulfur contents from 0.04 to $0.4 \mathrm{wt} . \%$ and a wide range in Creq/Nieq ratios were studied. Tensile properties of welds with both processes were related to alloy composition and solidification microstructure. The yield and ultimate tensile strengths increased with increasing Creq/Nieq ratios and ferrite content, whereas the ductility measured by RA at fracture decreased with sulfur content. Nevertheless, a range in alloy compositions was identified that provided a good combination of both strength and ductility. The solidification cracking response for the same large range of compositions are discussed, and compositions identified that would be expected to provide good performance in welded applications.
\end{abstract}




\section{Contents}

Acknowledgements ........................................................................................................... 6

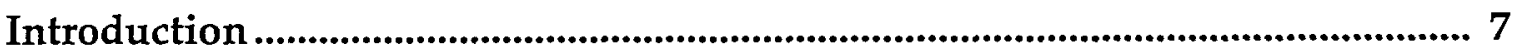

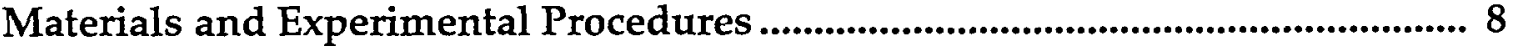

GTA Weld Results .............................................................................................................. 8

EB Weld Results ............................................................................................................... 13

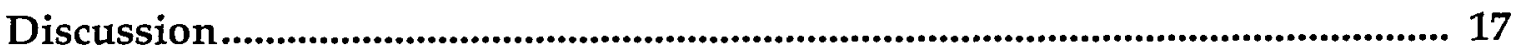

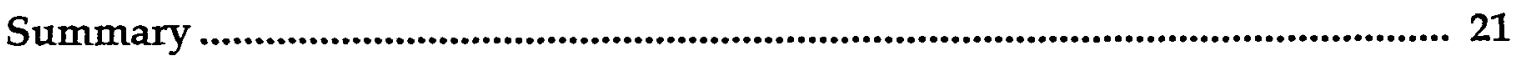

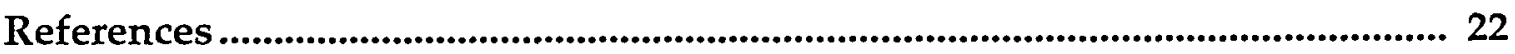




\section{Illustrations}

No.

1. Schematic of weld solidification and and solid-state transformation behavior shown for increasing $\mathrm{Cr}_{\mathrm{eq}} / \mathrm{Ni}_{\mathrm{eq}}$ ratio.

2. Microstructure of GTA welds, (A) Heat 7, Creq/Nieq $=1.55, \mathrm{~S}=0.11$, (B) Heat 9 Creq/Nieq $=1.74, S=0.27$, (C) Heat 2, Creq/Nieq=1.95, $S=0.04$, (D) Heat 6, Creq/Nieq $=1.92, \mathrm{~S}=0.42$.

3. Yield strength vs. FN for GTA all weld metal tensile samples.

4. Uniform elongation and reduction in area vs. sulfur content of all weld metal GTA tensile samples.

5. GTA Tensile fracture surfaces at a sulfur level of $0.04 \mathrm{wt} . \%$ (Heat 2) and (B) sulfur level of $0.27 \mathrm{wt} . \%$ (Heat 9) and (C) sulfur level of $0.42 \mathrm{wt. \%}$ (Heat 6). Note second phase $\mathrm{Mn}$ and $\mathrm{Cr}$ containing sulfides.

6. Microstructures of EB welds (A) Heat 7, $\mathrm{Cr}_{\mathrm{eq}} / \mathrm{Ni}_{\mathrm{eq}}=1.74, \mathrm{~S}=0.11 \mathrm{wt}$. \%, (B) Heat 9, $\mathrm{Cr}_{\mathrm{eq}} / \mathrm{Ni}_{\mathrm{eq}}=1.74, \mathrm{~S}=0.27 \mathrm{wt} . \%$, (C) Heat $6, \mathrm{Cr}_{\mathrm{eq}} / \mathrm{Ni}_{\mathrm{eq}}=1.92, \mathrm{~S}=0.42 \mathrm{wt} . \%$.

7. Comparison of EB and GTA tensile strengths vs. ferrite number. 16

8. Reduction in area at fracture of EB and GTA welds vs. sulfur content. 17

9. SEM images of fracture surface of EB tensile specimen of Heat. (A) Low magnification showing crack on the upper left of the fracture surface; (B) higher magnification of solidification crack surface showing sulfides stringers transverse to the solidification direction; $(C)$ fracture surface at center of specimen exhibiting a columnar structure and underlying ductile fracture typical of all the specimens.

10. EB tensile fractures showing change in appearance with increasing sulfur content: (A) Heat 1 with 0.04 wt.\% S; (B) Heat 7 with 0.11 wt.\% S; and (C) Heat 6 with $0.042 \mathrm{wt} . \% \mathrm{~S}$. The fracture is seen to initiate at sulfides with a variety of sizes and morphologies.

11. Solidification cracking susceptibility of GTA and pulsed YAG laser welds showing region of cracking behavior for both processes (Ref.4). 21

\section{Tables}

No.

1. Alloy compositions, calculated Creq/Nieq ratios, and ferrite numbers (FN).

2. All weld metal GTA tensile properties

3. All Weld Metal Electron Beam Tensile Properties. 


\section{Acknowledgements}

Special thanks is given to Andy Gardea, Jeff Chames, Alice Kilgo, and Bonnie McKenzie, for metallographic services and to Annette Newman for laboratory support on weldability testing. Appreciation is also given to Carpenter Technology Corporation for supplying the experimental alloys 


\section{Weld Properties of a Free Machining Stainless Steel}

\section{Introduction}

Austenitic stainless steels are used in a wide range of applications, often because of their good corrosion resistance, mechanical behavior, and magnetic properties. However, because of their high work-hardening rate, toughness, and ductility, these materials are known to be difficult to machine. In general, tools run hotter with more tendency to form buildup at the tool edge, chips are stringier with the tendency to tangle, tool chatter can be exacerbated, and feed rate can be more critical than with other materials. The use of free machining grades can greatly reduce machining time and improve surface quality. Commonly, the free machining grades are alloyed with small amounts of low solubility elements such as sulfur, lead, and selenium. These elements aid machinability by forming precipitates or inclusions that cause the chip to break into short pieces instead of continuing as lengthy turnings. Also the inclusions appear to help lubricate the tip of the tool at the cutting edge that minimizes galling and seizing.

Free machining stainless steels have seen little use in applications involving welding. The two concerns restricting their use are weld hot cracking and uncertainties in weld mechanical properties. However, it has been shown for AISI 303, the most widely used free machining grade (alloyed with sulfur), that if the welds solidify as primary ferrite they can be very resistant to cracking (Refs. 1-4).

For gas-tungsten arc (GTA) welds, the critical Creq/Nieq ratio for ferrite solidification was found (Refs. 3, 4), when using Hammer and Svensson equivalents (Ref. 5), to be in the range of 1.55-1.6. For pulsed laser beam welds, the critical value was found to increase to $\sim 1.75$ (Refs. $3,4)$. In essence, this is due to the fact that higher Creq/Nieq ratios are required to maintain ferritic solidification at higher solidification velocities where dendrite tip undercooling increases more rapidly with increasing solidification velocity during ferrite solidification than during that of austenite (Refs. 6-12).

It was also shown in Ref. 4 that at higher sulfur levels, the transition in solidification mode appeared to be shifted to slightly higher Creq/Nieq ratios. Moreover, it was observed for GTA welds, that solidification cracking susceptibility increased for Creq/Nieq ratios above $\sim 1.9$. It should also be noted that the heats studied contained a high level of phosphorous that is also known to promote cracking (Refs. 13-16). Nevertheless, with high levels of sulfur, a range in compositions that contained Creq/Nieq ratios between $\sim 1.7$ to 1.9 showed good welding behavior for both GTA and laser welding processes. These two processes cover an extremely wide range in solidification velocities.

The second area of concern with high sulfur levels is the uncertainty in weld mechanical properties. The presence of solidification cracks could certainly have a catastrophic effect on weld strength and ductility. However, in the absence of solidification defects, the presence of Mn and $\mathrm{Cr}$ containing sulfides may, in themselves, be expected to have an adverse affect on weld 
properties. A goal of this study was to determine the effects of sulfur content and $\mathrm{Creq} / \mathrm{Nieq}$ ratio on all weld metal tensile properties of crack free GTA and EB welds. The alloys used to study mechanical properties were identical to those used in the earlier solidification and cracking studies (Ref. 3, 4).

\section{Materials and Experimental Procedures}

The chromium and nickel contents were adjusted to provide a range of $\mathrm{Cr}_{\mathrm{eq}} \mathrm{Ni}_{\mathrm{eq}}$ ratios in ten experimental induction melted heats of AISI 303 stainless steel. The 11-kg cast ingots were homogenized and hot rolled into strips $\sim 7.6 \mathrm{~cm}$ wide and $3.2 \mathrm{~mm}$ thick. As can be seen in Table 1 , all other alloying elements were held constant except for sulfur that was varied from 0.04 to $0.4 \mathrm{wt} . \%$. Phosphorous, an impurity known to promote solidification cracking, was held at the maximum allowable level of $0.03 \mathrm{wt} \%$ and should therefore represent a worst case. Table 1 also includes the $\mathrm{Cr}_{\mathrm{eq}} / \mathrm{Ni}_{\mathrm{eq}}$ ratios calculated using the equivalents of both Hammer and Svensson (Ref. 5) and those of the WRC 92 diagram (Ref. 17). It can be seen that the $\mathrm{Cr}_{\mathrm{eq}} / \mathrm{Ni}_{\mathrm{eq}}$ ratios range from 1.55 to 1.94. The ferrite number (FN) shown in Table 1 are those calculated using the WRC 92 diagram and are very similar to those calculated using the DeLong diagram (Ref. 18).

All weld metal GTA tensile specimens were made from 3.2-mm-thick plates welded from each side to produce full penetration welds that were approximately $6 \mathrm{~mm}$ wide at the surface. The welds were made using $120 \mathrm{~A}, 9.3 \mathrm{~V}$ with Ar shielding at a travel speed of $3 \mathrm{~mm} \mathrm{~s}^{-1}$. Flat, dogbone tensile specimens machined from these welds were $1.3 \mathrm{~mm}$ thick and had a reduced gage section $3.2 \mathrm{~mm}$ wide and $19 \mathrm{~mm}$ long. Electron beam welds made from the same plate were also butt welded from each side. Welds were made at $25.4 \mathrm{~mm} / \mathrm{sec}$ using $130 \mathrm{kV}$ and $32 \mathrm{~mA}$ with circular deflection and a defocused beam. Flat tensile specimens used for the all weld metal EB tensile properties were $2.54 \mathrm{~mm}$ wide and $1.27 \mathrm{~mm}$ thick. Samples were tested using with a non-contacting, laser extensometer at an initial strain rate of $0.005 \mathrm{~s}^{-1}$.

\section{GTA Weld Results}

The GTA weld microstructures corresponded closely to those expected from consideration of the $\mathrm{Cr}_{\text {eq }} / \mathrm{Ni}_{\text {eq }}$ ratios (Refs. 19-23). A schematic of the solidification behavior and idealized microstructures is shown in Fig. 1 with $\mathrm{Cr}_{\mathrm{eq}} \mathrm{Ni}_{\mathrm{eq}}$ ratio increasing from left to right. The two schematic representations at the left of the figure correspond to primary austenite solidification, with the one at the higher ratio depicting solidification with some eutectic ferrite (austenite/ferrite solidification). The three primary ferrite solidified structures are shown in the right side of the figure. The change in solidification mode from primary austenite to primary ferrite increases with increasing solidification velocity, but for typical GTA welds when using Hammer and Svensson equivalents occurs at a $\mathrm{Cr}_{\mathrm{eq}} / \mathrm{Ni}_{\text {eq }}$ ratio of $\sim 1.5$ (Refs. 19-21,24). However, it should be noted that welds often contain several of the microstructures shown adjacently in the schematic of Fig. 1. 
Table 1. Alloy compositions, calculated Creq/Nieq ratios, and ferrite numbers (FN).

\begin{tabular}{|c|c|c|c|c|c|c|c|c|c|c|}
\hline $\begin{array}{l}\text { Heat No. } \\
\text { /wt. \% }\end{array}$ & 1 & 2 & 3 & 4 & 5 & 6 & 7 & 8 & 9 & 10 \\
\hline$S$ & 0.04 & 0.04 & 0.04 & 0.11 & 0.27 & 0.42 & 0.11 & 0.12 & 0.27 & 0.18 \\
\hline $\mathrm{Cr}$ & 17.55 & 19.18 & 18.37 & 18.45 & 18.47 & 18.45 & 16.87 & 17.78 & 17.77 & 18.16 \\
\hline $\mathrm{Ni}$ & 10.51 & 8.92 & 9.73 & 8.60 & 8.49 & 8.61 & 10.08 & 9.29 & 9.30 & 8.83 \\
\hline $\mathrm{C}$ & 0.03 & 0.03 & 0.03 & 0.03 & 0.03 & 0.03 & 0.03 & 0.03 & 0.03 & 0.03 \\
\hline $\mathrm{Mn}$ & 1.48 & 1.49 & 1.48 & 1.49 & 1.48 & 1.48 & 1.47 & 1.48 & 1.49 & 1.47 \\
\hline $\mathrm{Si}$ & 0.62 & 0.59 & 0.62 & 0.61 & 0.57 & 0.57 & 0.59 & 0.61 & 0.59 & 0.61 \\
\hline$P$ & 0.03 & 0.03 & 0.03 & 0.03 & 0.03 & 0.03 & 0.03 & 0.03 & 0.03 & 0.03 \\
\hline Mo & 0.35 & 0.35 & 0.35 & 0.35 & 0.35 & 0.35 & 0.35 & 0.35 & 0.35 & 0.35 \\
\hline $\mathrm{Cu}$ & 0.31 & 0.30 & 0.30 & 0.30 & 0.30 & 0.30 & 0.30 & 0.31 & 0.30 & 0.30 \\
\hline$N$ & 0.02 & 0.02 & 0.02 & 0.02 & 0.02 & 0.02 & 0.02 & 0.02 & 0.02 & 0.02 \\
\hline $\begin{array}{l}\mathrm{Cr}_{\mathrm{eq}} / \mathrm{Ni}_{\mathrm{eq}} \\
W R C 92\end{array}$ & 1.48 & 1.89 & 1.67 & 1.85 & 1.87 & 1.85 & 1.48 & 1.67 & 1.67 & 1.78 \\
\hline $\mathrm{Cr}_{\mathrm{eq}} / \mathrm{Ni}_{\mathrm{eq}} \mathrm{H} \& S$ & 1.55 & 1.95 & 1.73 & 1.92 & 1.94 & 1.92 & 1.55 & 1.74 & 1.74 & 1.85 \\
\hline FN, WRC92 & 2 & 14 & 10 & 12 & 12 & 12 & 1.5 & 6 & 6 & 9 \\
\hline
\end{tabular}

The heats with a $\mathrm{Cr}_{\mathrm{eq}} / \mathrm{Ni}_{\mathrm{eq}}$ ratio of 1.55 solidified in a mixed mode, with some regions of primary austenite with eutectic ferrite, and others as primary ferrite with skeletal ferrite. This $\mathrm{Cr}_{\mathrm{eq}} / \mathrm{Ni}_{\mathrm{eq}}$ ratio is close to that where the transition in solidification mode is commonly believed to change from primary austenite to primary ferrite (Refs. 19-21). However, in general, it was found that the two heats solidified somewhat differently. Heat 7 with the higher sulfur content, $0.11 \mathrm{wt} . \%$, solidified largely as primary austenite while Heat 1 with $0.04 \mathrm{wt} . \%$ sulfur solidified largely as primary ferrite.

The microstructure of Heat 7 is shown in Fig. 2(A) and is characteristic of primary austenite solidification in which a small amount of eutectic ferrite is contained at the solidification cell and grain boundaries (austenite/ferrite solidification, see Fig. 1). Large numbers of sulfide inclusions are also present and confined to the solidification boundaries. Scanning electron microscopy (SEM) with energy dispersive spectrometry (EDS) analysis showed that the sulfides contain manganese with smaller amounts of chromium.

The weld microstructure of Heat 9 with a sulfur content of 0.27 wt.\% shown in Fig. 2(B), is characteristic of welds with $\mathrm{Cr}_{\mathrm{eq}} / \mathrm{Ni}_{\mathrm{eq}}$ ratios of $\sim 1.7$. The primary ferrite solidified weld (ferrite/austenite solidification) exhibits a skeletal ferrite morphology. However, at this $\mathrm{Cr}_{\mathrm{eq}} / \mathrm{Ni}_{\text {eq }}$ ratio, some regions of lathy ferrite (see Fig. 1.) were also observed. Large amounts of sulfides are 
again present both along the solidification cell boundaries as well as along ferrite austenite interphase boundaries. This primary ferrite skeletal structure is similar to the primary ferrite solidified regions of the welds with the $\mathrm{Cr}_{\mathrm{eq}} / \mathrm{Ni}_{\mathrm{eq}}$ ratio of 1.55 .

The final weld microstructures, Figs. 2(C) and (D), are those from heats with the highest Creq/Nieq ratio of $\sim 1.9$. The microstructure of Heat 2 with a $\mathrm{Cr}_{\mathrm{eq}} / \mathrm{Ni}_{\mathrm{eq}}$ ratio of 1.95 and a sulfur content of 0.04 wt.\% is shown in Fig. 2(C). This weld exhibits primarily a lathy ferrite structure where it is evident that the laths extend over several solidification cells, and that solidification occurred completely as ferrite (Refs. 19-20). Small sulfide particles are present at both intradendritic ferrite austenite boundaries and within the solidification boundaries. The presence of intracellular sulfides indicates that, unlike primary austenite solidification, some of the liquid sulfides are trapped during ferrite solidification, rather than rejected to the cell boundaries.

The weld microstructure of Heat 6 with a Creq/Nieq of 1.92 and the highest S content, $0.42 \mathrm{wt} . \%$, is shown in Fig. 2(D). Large quantities of sulfides are present along both the solidification cell boundaries and the ferrite austenite interphase boundaries. However, clusters of finer sulfide particles at the interdendritic regions are also present at this high sulfur content.

Figure 1. Schematic of weld solidification and and solid-state transformation behavior shown for increasing $\mathrm{Creq} / \mathrm{Nieq}$ ratio.

EMBED Word.Picture.8

(A)

(C)
(D)

Figure 2. Microstructure of GTA welds, (A) Heat 7, Creq/Nieq=1.55, $S=0.11$, (B) Heat 9 Creq/Nieq $=1.74, S=0.27$, (C) Heat 2, Creq/Nieq $=1.95, S=0.04,(D)$ Heat 6, Creq/Nieq=1.92, $\mathrm{S}=\mathbf{0 . 4 2}$.

Longitudinal, all weld metal GTA tensile properties are given in Table 2. The yield and ultimate tensile strengths, uniform and total elongation, and reduction in area at fracture (RA) are shown along with Creq/Nieq ratio and sulfur content and are the average of two tests per heat. The graphical representation of the data in Fig. 3 shows the correlation between strength and FN. It can be seen that an increase in calculated FN from 2 to $\sim 12$ resulted in a $\sim 25 \%$ increase in YS and a $15 \%$ increase in UTS.

The tensile ductility measured as uniform elongation and \% RA is plotted as a function of FN in Fig. 4. It can be seen that the elongation is in the range of $40-50 \%$ for sulfur levels below $0.4 \%$ and above $35 \%$ at the highest level tested. As can be seen in Table 2, the total elongation in most cases was just slightly greater than the uniform elongation, reflecting the very small amount of necking that occurred in the specimens prior to fracture. The \%RA shows a stronger and more 
systematic sulfur dependence, with measured \%RA decreasing from $\sim 55 \%$ at the lowest level of sulfur to less than $30 \%$ at $0.42 \mathrm{wt} . \%$.

The weld fracture surfaces were analyzed using SEM to determine the influence of microstructure on fracture. The results of these evaluations are shown in Fig. 5(A-C) for welds with sulfur contents of $0.04,0.27$ and $0.42 \mathrm{wt} . \%$. In all cases fracture occurred by microvoid coalescence where the microvoids initiated at second phase (primarily sulfide) particles. However, it is apparent that the average dimple size decreases as the sulfur content increases.

Table 2. All weld metal GTA tensile properties.

\begin{tabular}{cccccccc}
\hline Heat No. & $\begin{array}{c}\text { Creq/Ni } \\
\text { eq }\end{array}$ & $\begin{array}{c}\text { S } \\
(\mathrm{wt} \%)\end{array}$ & $\begin{array}{c}\text { YS } \\
(\mathrm{MPa})\end{array}$ & $\begin{array}{c}\text { UTS } \\
\mathrm{MPa}\end{array}$ & $\begin{array}{c}\% \mathbf{\%} \\
(\%)\end{array}$ & $\begin{array}{c}\mathrm{T} \\
(\%)\end{array}$ & $\begin{array}{c}\mathrm{RA} \\
(\%)\end{array}$ \\
\hline 1 & 1.55 & 0.04 & 276.3 & 581.2 & 48.7 & 51.1 & 53 \\
2 & 1.95 & 0.04 & 312.5 & 630.4 & 40.2 & 44.6 & 63 \\
3 & 1.73 & 0.04 & 308.7 & 610.4 & 44.7 & 47.8 & 58 \\
4 & 1.92 & 0.11 & 313.8 & 651.1 & 47.2 & 50.0 & 46 \\
5 & 1.94 & 0.27 & 329.3 & 645.2 & 43.0 & 43.3 & 32 \\
6 & 1.92 & 0.42 & 324.5 & 637.7 & 36.6 & 36.7 & 28 \\
7 & 1.55 & 0.11 & 259.8 & 564.3 & 49.3 & 50.5 & 47 \\
8 & 1.74 & 0.12 & 289.4 & 613.9 & 46.8 & 49.5 & 51 \\
9 & 1.74 & 0.27 & 296.3 & 624.6 & 46.7 & 47.6 & 37 \\
10 & 1.85 & 0.18 & 300.6 & 634.6 & 47.7 & 48.2 & 40
\end{tabular}

Figure 3. Yield strength vs. FN for GTA all weld metal tensile samples.

Figure 4. Uniform elongation and reduction in area vs. sulfur content of all weld metal GTA tensile samples.

\section{EB Weld Results}

The EB weld microstructures were similar to those of the GTA welds of the same composition. The primary difference was that the EB welds exhibited a finer structure due to the higher solidification velocity and cooling rates. The primary austenite solidified microstructure of Heat 7, Fig. 6(A), is characteristic of both heats with the Creq/Nieq ratio of 1.55. Unlike the GTA welds, little eutectic ferrite and no regions of primary ferrite were observed. It can be seen that all the sulfides are again confined to the solidification boundaries. The microstructure of heats with a Creq/Nieq ratio of 1.74 exhibited mainly skeletal ferrite. This is shown in Fig. 6(B) 
for Heat 9. It is also very evident with the primary ferrite solidified structure the sulfides are not confined only to the cell boundaries but a fraction are also trapped within the intradendritic regions. This observation again demonstrates the differences between the two different solidification modes in terms of sulfide trapping at the solid liquid interface. The welds with the highest Creq/Nieq ratios ( 1.94) solidified as primary ferrite and exhibited a mixture of skeletal and lathy ferrite, Fig. $6(\mathrm{C})$.

The EB all weld metal tensile properties are given in Table 3. Again the results are averages of two tests per heat (except for Heats 7 and 10). One of the Heat 7 specimens exhibited both low strength and low ductility, only a little over $10 \%$ elongation. This sample also exhibited large amounts of secondary cracking along the gage length. SEM examination of fracture surfaces of this specimen, and both specimens from Heat 1 , showed evidence of prior solidification cracks. 


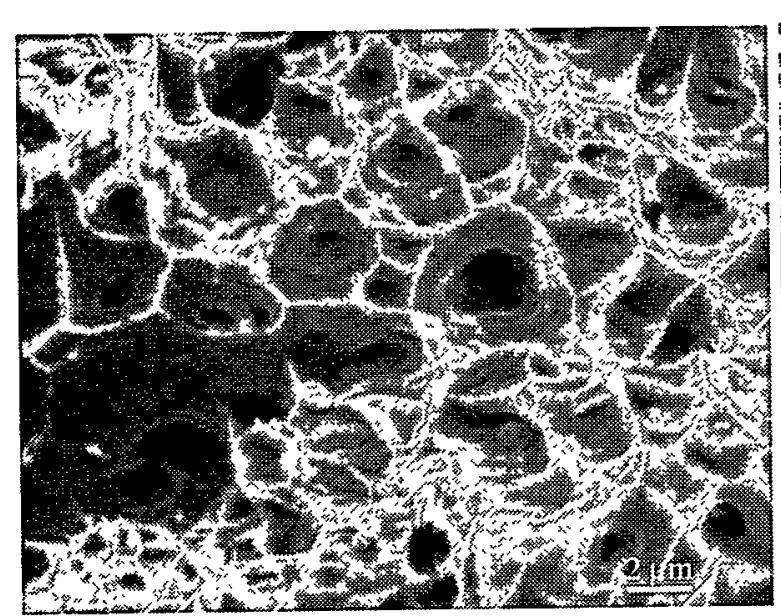

(A)

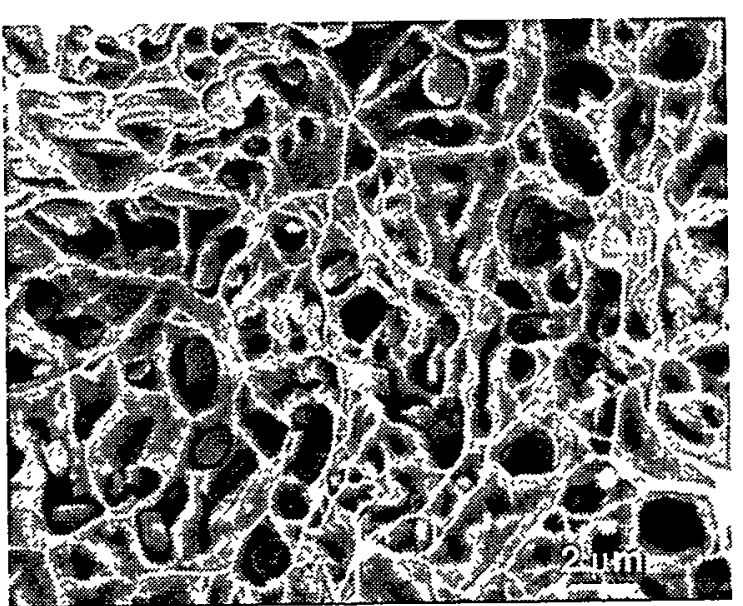

(B)

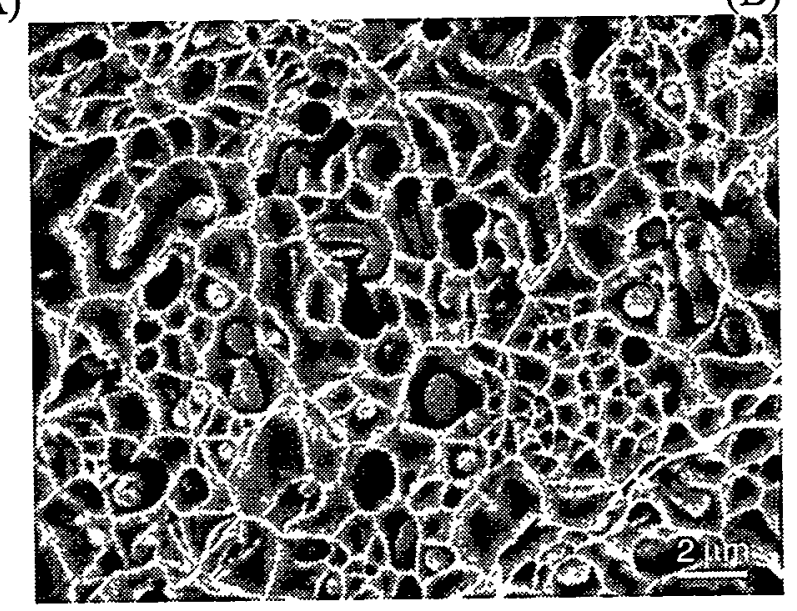

(C)

Figure 5. GTA Tensile fracture surfaces at a sulfur level of 0.04 wt. $\%$ (Heat 2) and (B) sulfur level of 0.27 wt.\% (Heat 9) and (C) sulfur level of 0.42 wt.\% (Heat 6). Note second phase $\mathrm{Mn}$ and $\mathrm{Cr}$ containing sulfides.

The tensile properties were therefore controlled largely by weld defects, the solidification cracks, rather than the weld microstructure. Thus the data in Table 3 for Heat 1 is characteristic of welds with these defects. The results from the one Heat 7 specimen were not included in the data in Table 3. The EB tensile strengths plotted for all the weld heats except for Heat 1 are shown in Fig. 7 along with the GTA weld data. It can be seen that similar to the GTA welds, both the yield and tensile strengths increase with FN. The ductility, plotted as \% RA vs. sulfur content is shown in Fig.8. Again, there is a strong correlation between fracture behavior and sulfur content and the behavior is similar for both processes, although the ductility of the EB welds is slightly lower on average

The EB weld fracture surfaces were also examined by electron microscopy. The welds from Heat 1 with a Creq/Nieq ratio of 1.55 and 0.04 wt. \% sulfur and which exhibited both low strength and ductility were of special interest. Figure 9(A) shows at low magnification the weld fracture that exhibits a very prominent, flat appearing region on the upper left side of the fracture surface. Higher magnification shows that this region exhibits a very smooth columnar 
appearance with evidence of fine surface porosity. Also, transverse to the solidification direction were sulfides associated with the solidification crack that had a rather unusual stringer morphology. A region near the center of the specimen is shown in Fig. 9(C). In this location, the fracture surface exhibits a very prominent columnar appearance, with a finer scale ductile rupture. Thus, the low strength and ductility of these welds can be attributed to pre-existing solidification cracks. It can be seen in Fig. 9(a) that considerable necking had occurred prior to premature failure resulting from the large defect. A similar but smaller solidification crack region was observed in one of the welds of Heat 7 which again resulted in poor weld properties. As noted above, the results from this specimen were not included in the data plotted in Figs. 7 and 8.

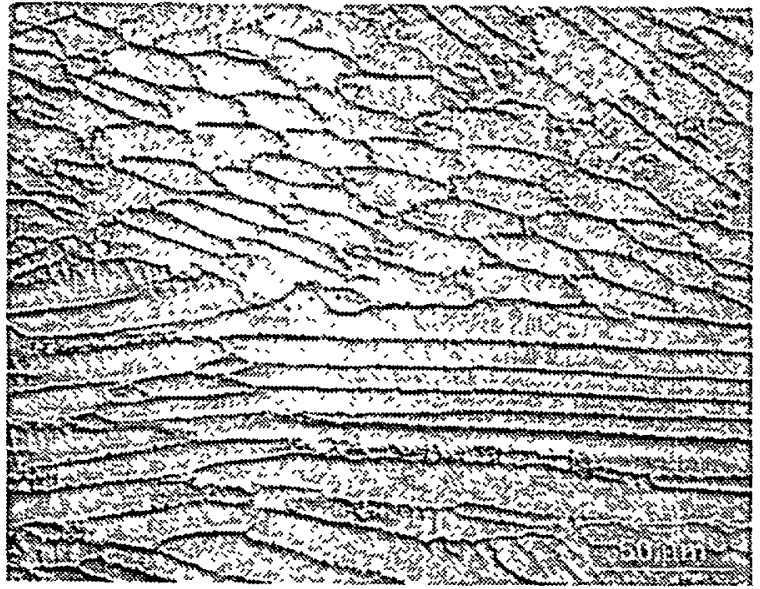

(A)

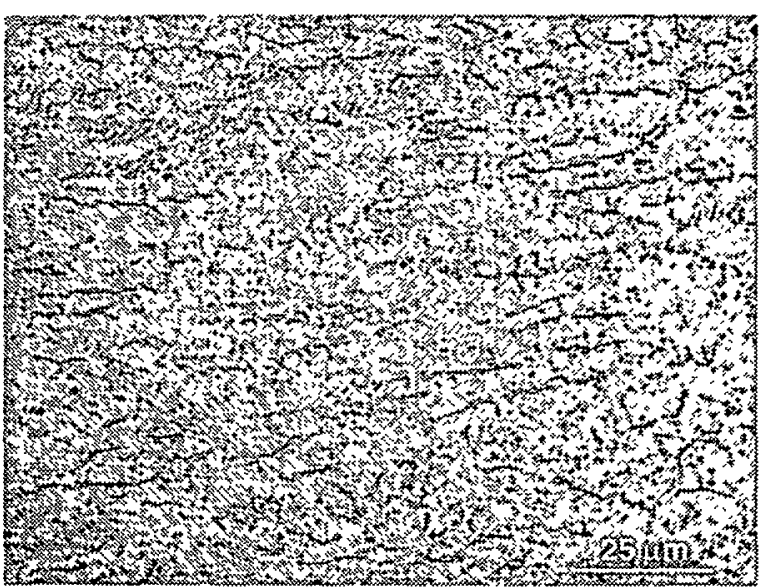

(B)

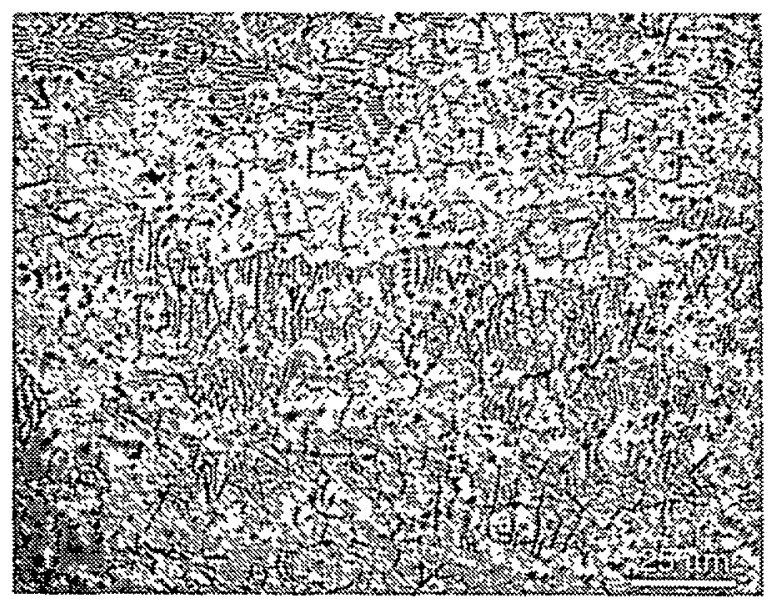

(C)

Figure 6. Microstructures of EB welds (A) Heat 7, $\mathrm{Cr}_{\mathrm{eq}} / \mathrm{Ni}_{\mathrm{eq}}=1.74, \mathrm{~S}=0.11 \mathrm{wt} . \%$, (B) Heat 9, $\mathrm{Cr}_{\mathrm{eq}} / \mathrm{Ni}_{\mathrm{eq}}=1.74, \mathrm{~S}=0.27 \mathrm{wt} \%$, (C) Heat $6, \mathrm{Cr}_{\mathrm{eq}} / \mathrm{Ni}_{\mathrm{eq}}=1.92, \mathrm{~S}=0.42 \mathrm{wt} . \%$. 
Table 3. All Weld Metal Electron Beam Tensile Properties.

\begin{tabular}{|c|c|c|c|c|c|c|c|}
\hline $\begin{array}{c}\text { Heat } \\
\text { No. }\end{array}$ & $\begin{array}{c}\mathrm{Cr}_{\text {eq }}{ }^{\prime} \\
\mathrm{Ni}_{\mathrm{eq}}\end{array}$ & $\begin{array}{c}\mathrm{S} \\
\text { (wt.\%) }\end{array}$ & $\begin{array}{c}\mathrm{YS} \\
(\mathrm{MPa})\end{array}$ & $\begin{array}{c}\text { UTS } \\
\text { (MPa) }\end{array}$ & $\begin{array}{l}\% \varepsilon_{\mathrm{u}} \\
(\%)\end{array}$ & $\begin{array}{c}\varepsilon_{T} \\
(\%)\end{array}$ & $\begin{array}{l}\text { RA } \\
(\%) \\
\end{array}$ \\
\hline $1^{a}$ & 1.55 & 0.04 & 253 & 413 & 16.1 & 16.6 & \\
\hline 2 & 1.95 & 0.04 & 339 & 645 & 41.2 & 48.2 & 57 \\
\hline 3 & 1.73 & 0.04 & 306 & 577 & 40.8 & 47.7 & 54 \\
\hline 4 & 1.92 & 0.11 & 338 & 654 & 43.4 & 46.9 & 41 \\
\hline 5 & 1.94 & 0.27 & 352 & 643 & 31.9 & 32 & 24 \\
\hline 6 & 1.92 & 0.42 & 373 & 635 & 28.6 & 28.7 & 21 \\
\hline 7 & 1.55 & 0.11 & 330 & 532 & 50.3 & 50.5 & 41 \\
\hline 8 & 1.74 & 0.12 & 303 & 595 & 43 & 48.6 & 44 \\
\hline 9 & 1.74 & 0.27 & 304 & 604 & 44.2 & 44.1 & 30 \\
\hline 10 & 1.85 & 0.18 & 341 & 654 & 42.4 & 42.7 & 29 \\
\hline
\end{tabular}

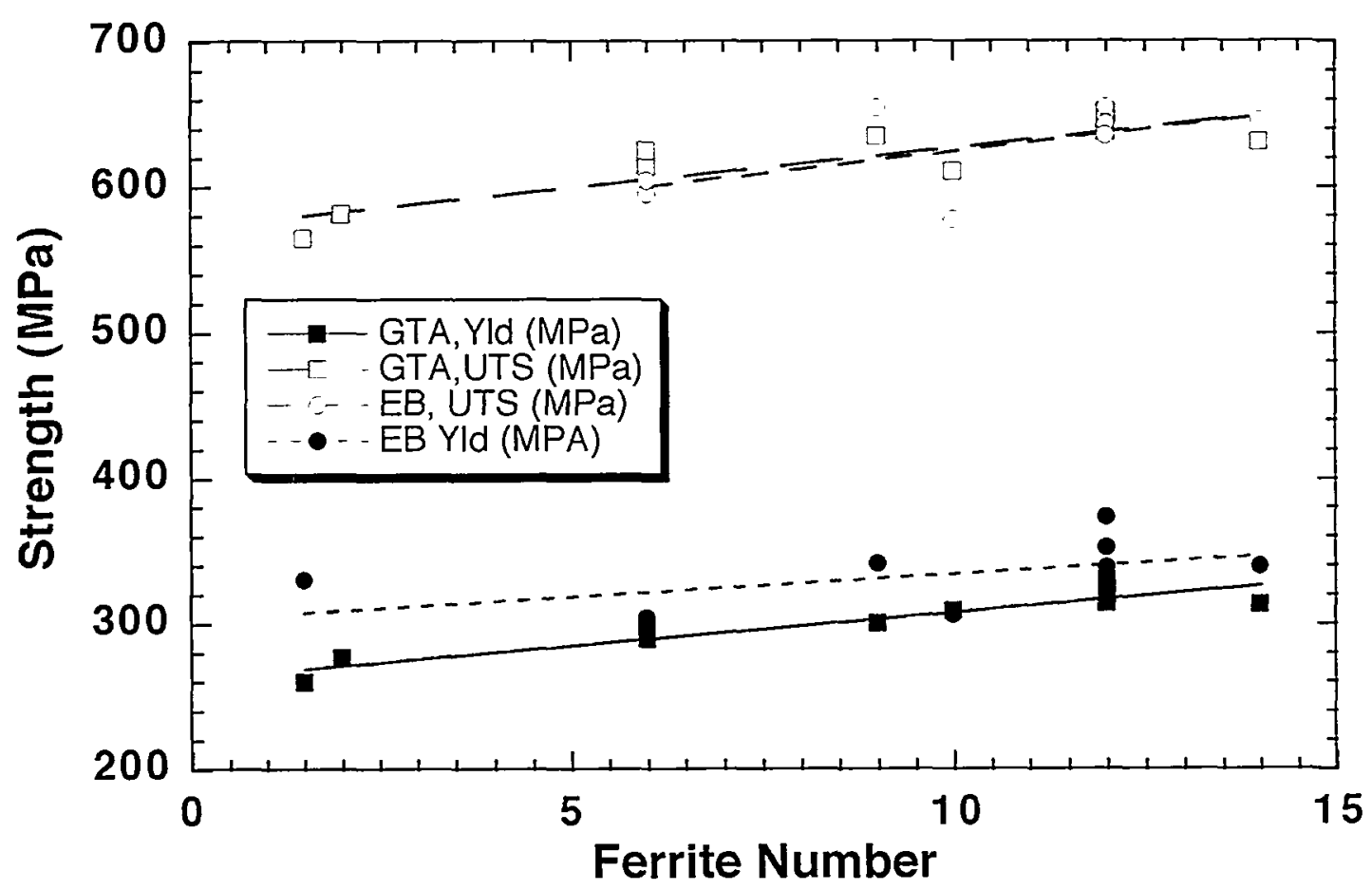

Figure 7. Comparison of EB and GTA tensile strengths vs. ferrite number. 


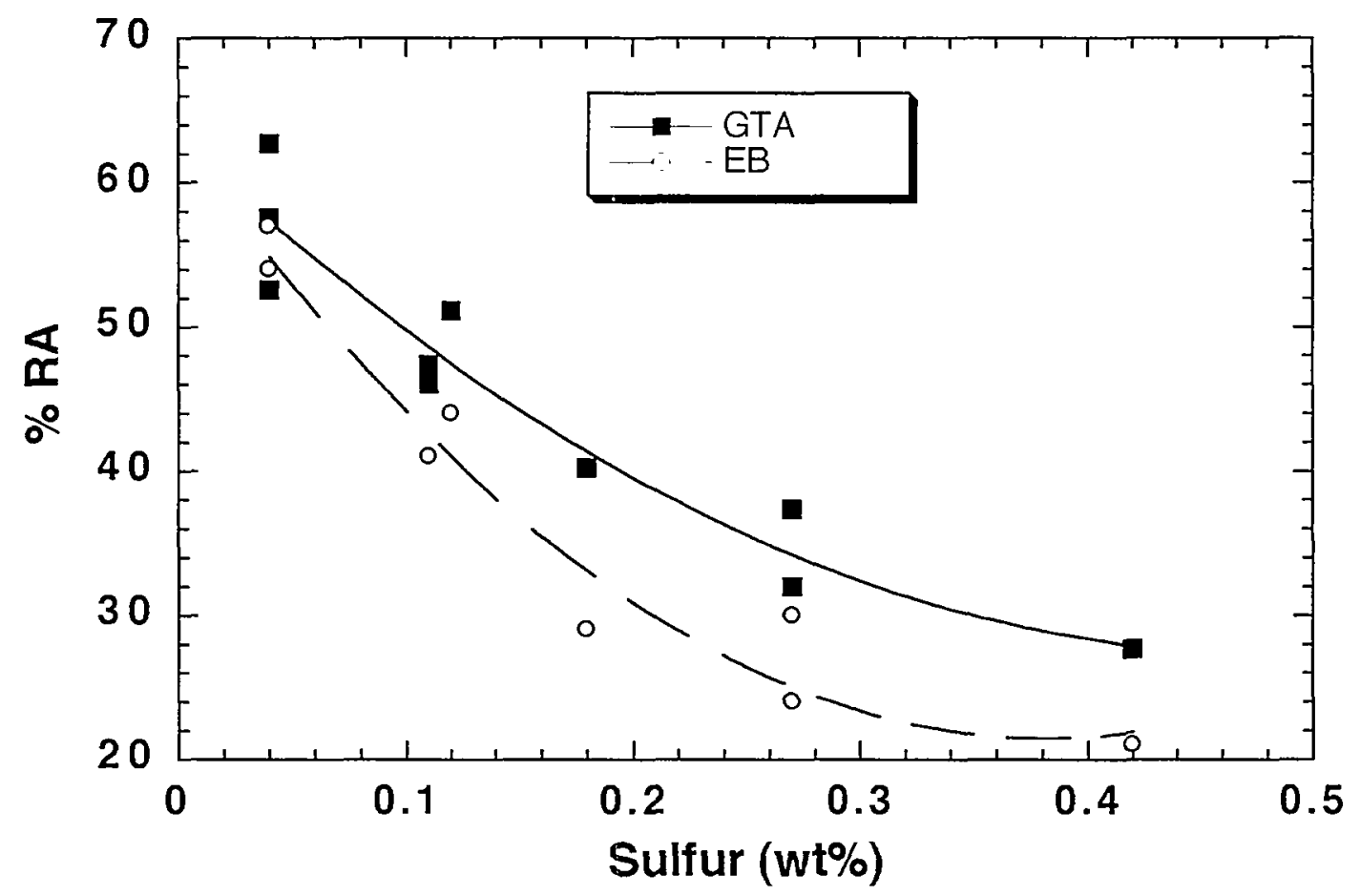

Figure 8. Reduction in area at fracture of EB and GTA welds vs. sulfur content.

In general the fracture appearance of all the EB specimens at low magnification exhibited a columnar dendritic appearance similar to that shown in Fig. 9(C). Furthermore, in all cases the fracture occurred by a ductile process with nucleation and growth of voids at sulfide particles. It was found that as the sulfur content increased, the size and area fraction of sulfides on the fracture increased. This observation is shown in Fig. 10 for sulfur contents of $0.04,0.11$, and $0.42 \mathrm{wt} . \%$. Fig. 10(A) shows that at the lowest sulfur concentration (0.04 wt.\%), the large majority of sulfides are spherical in shape and approximately 0.5 to 1 micron in diameter. It is clearly evident that fracture initiated at these particles. At a higher sulfur content $(0.11 \% \mathrm{wt} . \%)$, Fig. 10(B), a larger number of particles are evident, along with the accompanying smaller average dimple size. It can also be seen that some agglomeration of sulfides has occurred to form larger elongated particles. However, the majority of the sulfides remain spherical but slightly larger than observed at lower S levels. Fig. $10(\mathrm{C})$ shows that the sulfide morphology was significantly different at the highest level of sulfur, $0.42 \mathrm{wt} . \%$. Here, in addition to a few large, nearly spherical sulfides, a large number of agglomerated and elongated sulfides are also present. In addition there are numerous colonies of very fine spherical sulfides. It should be noted that the heat shown in Fig. 10(C) has one of the highest Creq/Nieq ratios.

\section{Discussion}

The GTA yield and tensile strengths shown in Fig. 3 increased 25 and 15\% respectively, with an increase in calculated FN from -2 to 12 . For the range in FN studied here, FN and \% ferrite are similar in value. Thus it appears that the increase in strength can be attributed largely to the presence of this second phase. Although there were a large number of sulfide particles, their rather large size does not appear to result in significant strengthening. 


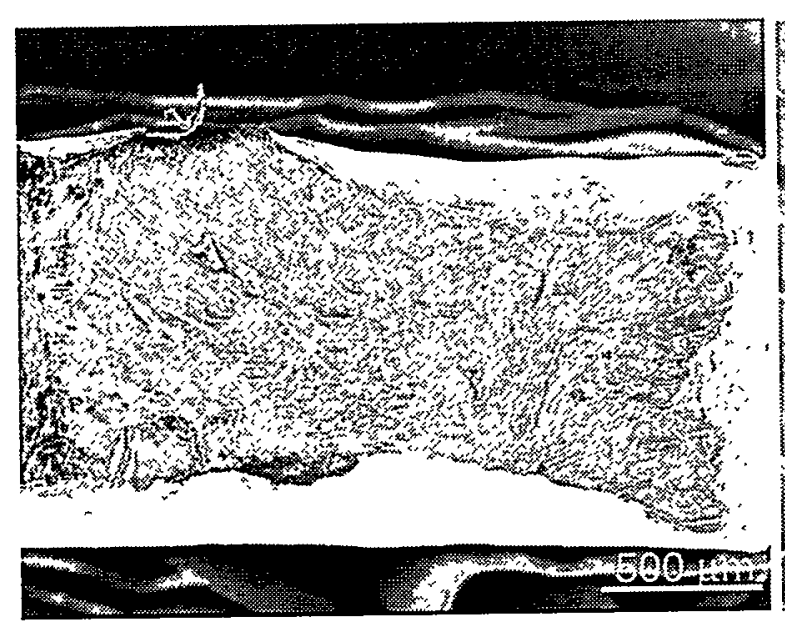

(A)

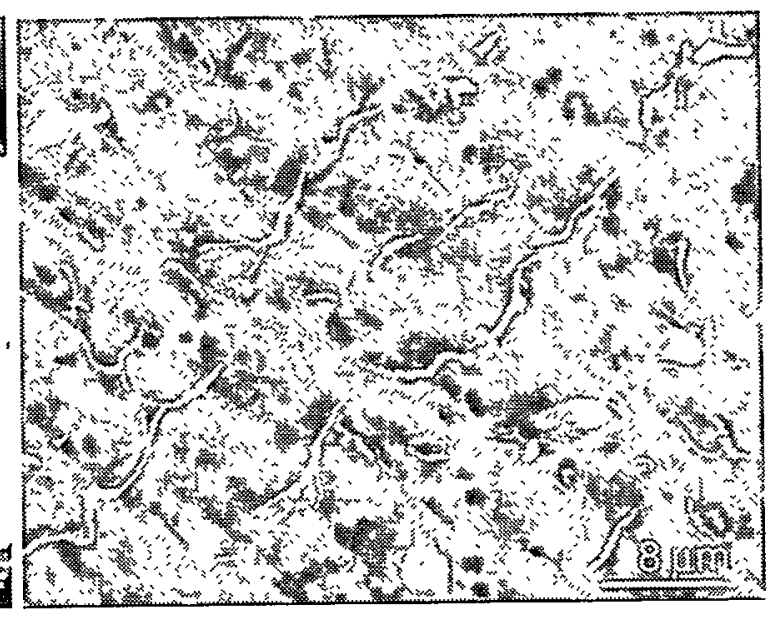

(B)

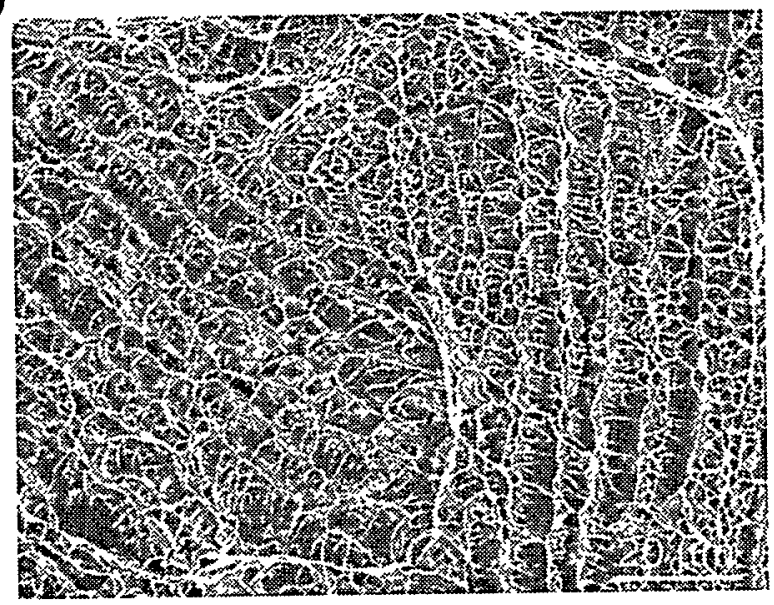

(C)

Figure 9. SEM images of fracture surface of EB tensile specimen of Heat. (A) Low magnification showing crack on the upper left of the fracture surface; (B) higher magnification of solidification crack surface showing sulfides stringers transverse to the solidification direction; (C) fracture surface at center of specimen exhibiting a columnar structure and underlying ductile fracture typical of all the specimens.

The ductilities of the GTA welds are plotted vs. sulfur content in Fig. 4. At the low S levels, $0.04 \mathrm{wt} . \%$, there is a range in RA and uniform elongation of $20 \%$ between heats with the three different $\mathrm{Cr}_{\text {eq }} / \mathrm{Ni}_{\mathrm{eq}}$ ratios. However, there is no consistent variation in ductility in that the heat with the highest uniform elongation, Heat 3 , has the lowest RA, whereas the heat with the lowest uniform elongation has the highest $\mathrm{RA}$. It may be expected that the heat with the lowest $\mathrm{Cr}_{\mathrm{eq}} / \mathrm{Ni}_{\mathrm{eq}}$ ratio that solidified as austenite, Heat 1 , would have a larger amount of sulfides due to a lower solubility of $\mathrm{S}$ in austenite than ferrite and to a smaller partitioning coefficient. Unlike the other two heats, the sulfides in the primary austenite structure are also confined to the solidification boundaries. Nonetheless it appears that any slight change in sulfide content and distribution due to the different weld microstructures had no consistent effect on weld ductility. 


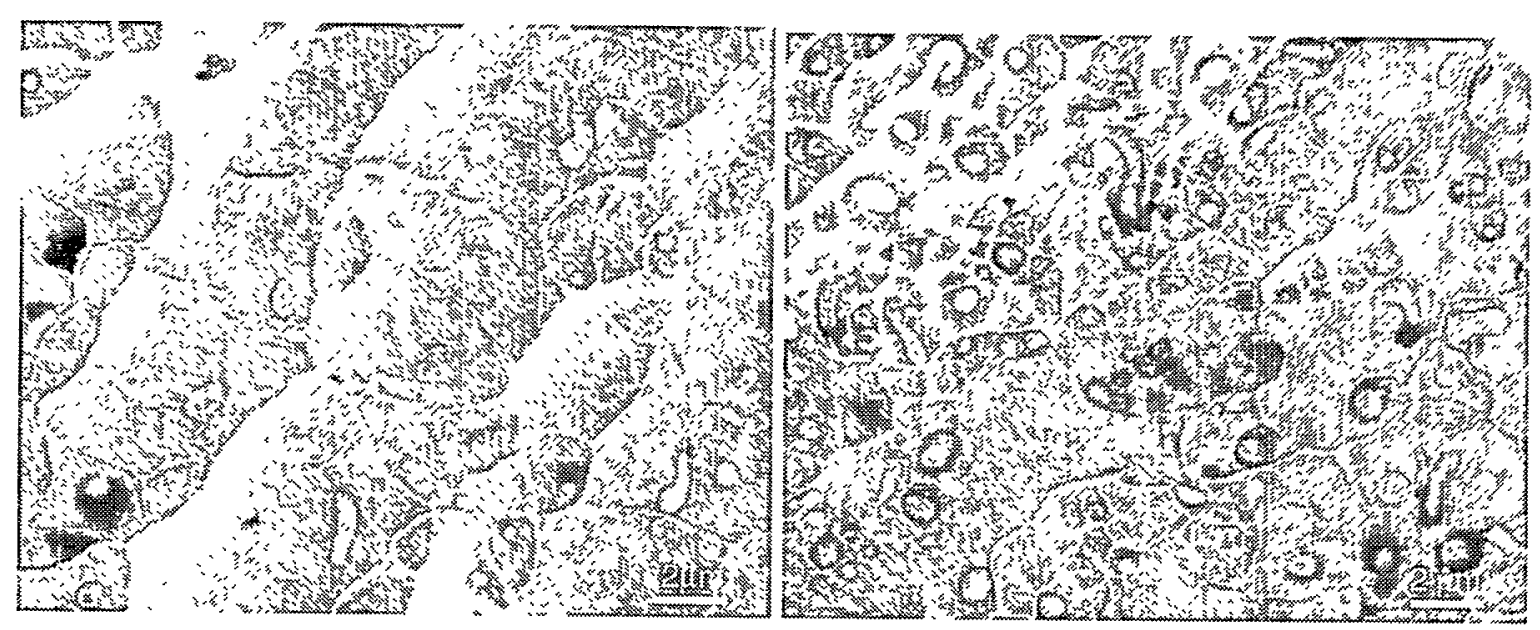

(A)

(B)

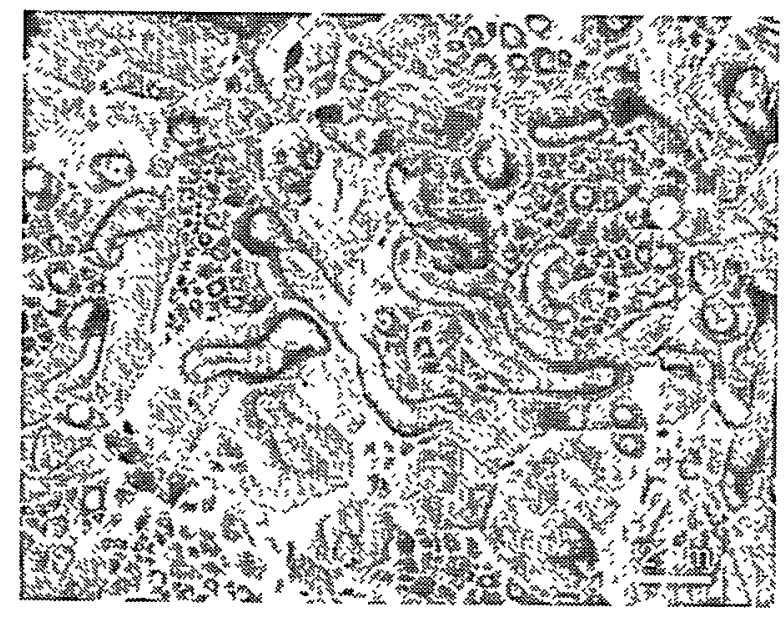

(C)

Figure 10. EB tensile fractures showing change in appearance with increasing sulfur content: (A) Heat 1 with 0.04 wt.\% S; (B) Heat 7 with 0.11 wt. \% S; and (C) Heat 6 with $0.042 \mathrm{wt} . \% \mathrm{~S}$. The fracture is seen to initiate at sulfides with a variety of sizes and morphologies.

Sulfur did have a large effect on ductility (Fig. 4) reducing the RA from $\sim 60 \%$ at the lowest sulfur level to $32 \%$ at the highest sulfur level independent of $\mathrm{Cr}_{\mathrm{eq}} / \mathrm{Ni}_{\mathrm{eq}}$ ratio. There was also a significant decrease in elongation at the very highest level of sulfur, $0.42 \mathrm{wt} . \%$. It was found in all cases where there were no preexisting weld defects that fracture occurred by microvoid initiation and coalescence. The void initiation occurred at sulfide particles that were primarily concentrated along solidification boundaries resulting in a columnar dendritic fracture appearance. The reduction in ductility with increasing sulfur content can be attributed to a higher number and size of fracture initiation sites that facilitates the ductile fracture process. The reduction of dimple size with increasing sulfur content is apparent in the fractrographs in Figs. 5. It can be seen in Fig. 5(C) that the clusters of fine sulfide particles, which are also evident in the optical micrograph in Fig. 2(C), play a major role in fracture behavior at the highest sulfur level. The acceleration of microvoid coalescence processes with increasing sulfur content also results 
in the reduction in elongation after the onset of necking. However, is should be noted that for sulfur levels as high as $\sim 0.3 \mathrm{wt} . \%$, the welds still exhibit a good combination of strength and ductility (uniform elongation over $\sim 40 \%$ ).

The EB welds exhibited mechanical behavior very similar to the GTA welds. The primary difference was attributed to solidification cracking that occurred in the welds with the lowest $\mathrm{Cr}_{\mathrm{eq}} / \mathrm{Ni}_{\mathrm{eq}}$ ratio, i.e. Heat 1 and one of the specimens from Heat 7. The tensile strengths are plotted in Fig. 7. It can be seen that the measured yield strengths are very similar for both processes, with those of the EB welds being perhaps slightly higher, $\sim 10 \%$. This increase may be due to the finer microstructure, as can be seen by comparing the microstructures in Figs. 2 and 6. It can also be seen in Fig. 7 that the yield strengths of the EB welds show less of a dependence on FN. Although FN was not experimentally measured, it appeared that the ferrite content of the EB welds was less than that of the GTA welds made on the same heats. The ultimate tensile strengths of the two weld processes are very similar.

The reduction in area at fracture for both processes is shown in Fig. 8. It can be seen that the trends are the same for both processes, with the RA decreasing with increasing sulfur content. The more precipitous decrease in RA might be expected for the EB welds since the dendrite spacing and sulfide size would both be smaller than in the GTA welds due to the higher cooling rate. This is apparent when comparing the micrographs in Figs. 2 and 6. The volume fraction of sulfides should remain nearly constant for the same heats with both welding processes except for a small reduction of sulfides in the EB welds due to higher solute trapping at the higher solidification velocities. Overall, with the finer solidification structure, the number of sulfide particles should be greater and the mean particle spacing less in the EB welds. Ductile fracture models predict in this case that the strain to fracture would decrease for the larger number of particles at the same volume fraction (Ref. 25).

The observation of cracks in $\mathrm{EB}$ welds with a $\mathrm{Cr}_{\mathrm{eq}} \mathrm{Ni}_{\mathrm{eq}}$ ratio of 1.55 is not unexpected for primary austenite solidification (Ref. 26). It is well known that welds that solidify as primary austenite are much more susceptible to solidification cracking than welds that solidify as primary ferrite (Refs. 27-31). It is also common that welds made with the high energy density (HED) processes and the associated high thermal gradients are more susceptible to cracking than conventional GTA welds. It was observed here that the GTA welds with $\mathrm{Cr}_{\mathrm{eq}} / \mathrm{Ni}_{\mathrm{eq}}$ of 1.55 solidified in a mixed mode, with the higher sulfur heat exhibiting a larger fraction of primary austenite solidification. An earlier study involving these alloys showed, that for $\mathrm{Cr}_{\text {eq }} / \mathrm{Ni}_{\text {eq }}$ ratios between 1.75 and 1.90, both GTA and pulsed laser welds exhibited good resistance to solidification cracking. The upper limit of $\mathrm{Cr}_{\mathrm{eq}} / \mathrm{Ni}_{\mathrm{eq}}$ ratio was set by the GTA process, and the lower limit by the high solidification rates of the pulsed laser welding process. These results are shown in Fig, 11, along with data from Pacary et al. (Ref. 31) where cracking susceptibility is plotted as (P+S) vs. $\mathrm{Cr}_{\mathrm{eq}} / \mathrm{Ni}_{\mathrm{eq}}$ ratio (using the equivalents of Hammer and Svennson).

At the $\mathrm{Cr}_{\mathrm{eq}} / \mathrm{Ni}_{\mathrm{eq}}$ ratios of $\sim 1.74$, the pulsed YAG laser welds solidified in a mixed mode of primary ferrite and primary austenite except for Heat 9 . This heat with the highest level of sulfur $(0.27 \mathrm{wt} . \%)$ solidified almost entirely as primary austenite and did exhibit a small amount of cracking. For the intermediate solidification velocities of the EB welds, the lower critical bound 
on $\mathrm{Cr}_{\mathrm{eq}} / \mathrm{Ni}_{\text {eq }}$ ratios can be expected to be between the two processes shown in Fig. 11. However, for EB welds this limit can be expected to be highly dependent upon weld solidification velocity (Refs. 12, 26). Of course, the degree of constraint also plays a critical role in solidification cracking behavior of primary austenite solidified welds.

From the mechanical property data reported here, and the weld cracking behavior summarized in Fig. 11, it can be seen that a range of compositions of free machining stainless steel exists that should provide a good combination of solidification cracking resistance and mechanical properties.

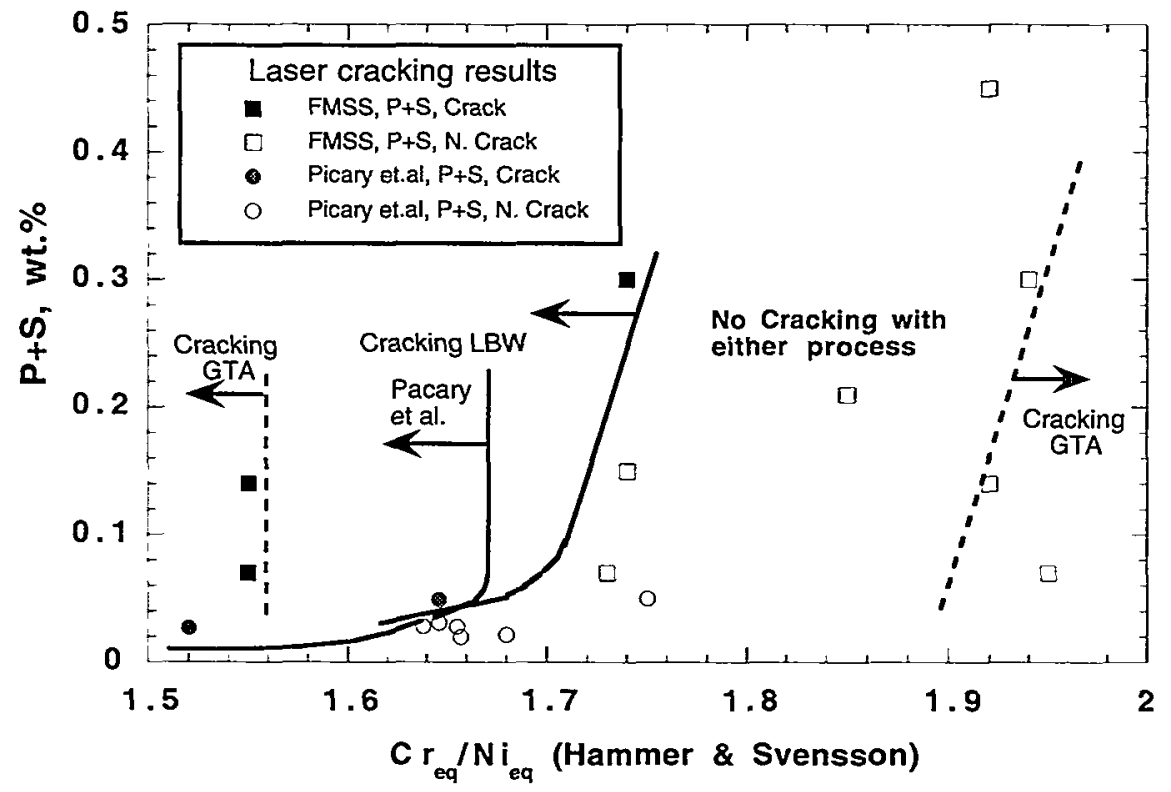

Figure 11. Solidification cracking susceptibility of GTA and pulsed YAG laser welds showing region of cracking behavior for both processes (Ref.4).

\section{Summary}

The all weld metal tensile behavior of both GTA and EB welds exhibited similar behavior over a wide range of $\mathrm{Cr}_{\text {eq }} / \mathrm{Ni}_{\text {eq }}$ ratios and sulfur contents. A slight increase in strength, $(\sim 15 \%)$ with increasing calculated $\mathrm{FN}$ was attributed primarily to second phase strengthening by ferrite. The wide range in sulfur, 0.04 to $0.42 \mathrm{wt} . \%$, had little if any effect on strength. At the lowest $\mathrm{Cr}_{\mathrm{eq}} / \mathrm{Ni}_{\mathrm{eq}}$ ratio of 1.55 , EB weld properties were largely controlled by the presence of solidification cracks that formed during primary austenite solidification.

A strong correlation was observed between sulfur content and ductility. This was attributed to the increase in $\mathrm{Cr}$ and $\mathrm{Mn}$ conteining sulfides with increasing sulfur content . In all cases, except in the presence of solidification cracks, fracture initiated at sulfides particles distributed mainly along solidification boundaries. The higher sulfide contents and closer spacing accelerated the ductile microvoid initiation and growth process responsible for the reduced ductility with increasing sulfur levels. The losses in RA with S content of the EB welds were somewhat higher than those of the GTA welds, which is likely associated with sulfide size and spacing. However, it was found that at moderate sulfur levels, a good combination of strength 
and ductility was achieved in both weld types. Based on solidification and cracking studies on the same alloys, it was found that a range of compositions of free machining stainless steels exist that should provide a good combination of solidification cracking resistance and weld properties for many engineering applications.

\section{References}

1. Lundin, C. D. Lee C. H., and Menon, R. 1988. Hot ductility and weldability of free machining austenitic stainless steel, Welding Journal, 67, (6): 122-s to 130-s.

2. Brooks, J. A., Thompson, A. W. and Williams, J. C. 1984. A fundamental study of the beneficial effect of delta ferrite in reducing weld cracking, Welding Journal 63 (2): 71 $\mathrm{s}$ to 83 -s.

3. Brooks, J., Robino, S. Goods, C., Headley, T., Knorovsky, G., Yang, N. 1999. Solidification and weldability of free machining stainless steel. International Conference on Joining of Advanced and Specialty Materials II, 1999 ASM Materials Solutions Conference and Exposition,Cincinnatti, $\mathrm{OH}$. ASM International.

4. Brooks, J., Robino, C., Headley, T., Michael, J. Knorovsky, G. 2000. Weld solidification and cracking behavior of free machining stainless steel. Submitted to Welding Journal.

5. Hammer, O. and Svensson, U. 1979. Influence of steel composition on segregation and microstructure during solidification of austenitic stainless steels, Solidification and Casting of Metals, The Metals Society, London: 401-410.

6. Vitek, J. M., Dasgupta, A., and David, S. A. 1983. Microstructural modification of austenitic stainless steels by rapid solidification. Metall. Trans A 14A: 1833-1841.

7. Katayama, S. and Matsunawa, A. Proc. ICALEO, San Francisco, 1985.

8. David, S.A., Vitek, J. M. and Hubble, T. L. 1987. Effect of rapid solidification on stainless steel microstructures and its implication on the Schaeffler diagram. Welding Journal 66 (10): 289-s.

9. Elmer, J. W., Allen, S. M., and Eagar, T. W. 1989.Microstructural development during solidification of stainless steel alloys. Metall. Trans 20A: 2117-2131.

10. Nakao, Y., Nishimoto, K. and Zhang, W. 1988, Effects of rapid solidification by laser surface melting on solidification modes and microstructure of stainless steel, Trans. JWJ:19:101.

11. Elmer, J. W. 1992. Non-equilibrium microstructures produced during electron-beam and laser-beam surface modification of metallic alloys, The Metals Science of Joining, ed Cieslak, Perepezko, Kang and Glicksman, TMS, Warrendale PA: 123-133.

12. Fukumoto, S. and Kurz, W. 1997. The $\delta-\gamma$ transition in Fe-Cr-Ni alloys during laser treatment, ISIJ International, 37 (7): 677-684. 
13. Borland, J. C. and Younger, R. N. 1960. Some aspects of cracking in welded Cr-Ni Austenitic steels, British Welding Journal, vol.7: 22-59.

14. Brooks, J. A. and Lambert, F. J. Jr. 1978. The effect of phosphorous and sulfur and ferrite content on weld cracking of type 309 stainless steel. Welding Journal: 51(5): 139-s.

15. Brooks, J. A. 1975. Weldability of high N, high Mn austenitic stainless steel. Welding Journal 54(6): 189 -s to 195 -s.

16. Li, L. and R. W. Messler, Jr. 1999. The effect of phosphorous and sulfur on susceptibility to weld hot cracking in austenitic stainless steels, Welding Journal 78(12): 387-s to 396-s.

17. Kotecki, D. and Siewert, T. A. 1992. WRC-1992 constitution diagram for stainless steel weld metals: a modification to the WRC-1988 diagram. Welding Journal 71(5): 171 -s to 179 -s.

18. Long, C.J., and DeLong, W.T. 1973. The ferrite content of austenitic stainless steel weld metal. Welding Journal 52(7): 281s-297s.

19. Suutula, N. , Takalo, T. and Moisio, T. 1979. Relationship between solidifiaction and microstructure in austenitic and austenitic-ferritic stainless steel welds. Metall. Trans ., 10A(4): 512-514

20. Takalo, T., Suutula, N. and Moisio, T. 1979. Metall. Trans , 10A(4), 1173-1181.

21. Suutula, N. 1982. Effect of solidification conditions on the solidification mode in austenitic stainless steels. Acta Universitatis Ouluensis, Sreries C Technica No. 23, University of Oulu, Oulu, Finland.

22. Brooks, J. A. and Thompson, A. W. 1991. Microstructural development and solidification cracking susceptibility of austenitic stainless steel welds. International Materials Reviews 36 (1): 16-44.

23. Olsen. D. L. 1985. Prediction of austenitic weld metal microstruture and properties. Welding Journal 64 (11):181-s to 295-s.

24. Suutala, N. 1982. Effect of manganese and nitrogen on the solidification mode in austenitic stainless steel welds. Acta Universitatis Ouluensis, Sreries C Technica No. 23, University of Oulu, Oulu, Finland.

25. Goods, S. H. and Brown, L. M. 1979. The nucleation of cavities by plastic deformation. Acta Metallurgicia, 27:1-15.

26. Laursen, B., Olsen, F., Yardy, J., Funder-Kristensen, T. 1997. Experimental determination of the primary solidification phase dependency on the solidification velocity of 17 different stainless steel compositions, preceedings ASM International conference on Welding and Joining Science and Technology, Madrid Spain, Mar 1022: 571-580 
27. Their, H. 1976. DVS-Berichte, Vol. 41. 100-104.

28. Arata, J., Matsuda, F., and Katayama, S. 1976. Fundamental investigation on solidification behavior of fully austenitic and duplex structures and effect of ferrite on microsegregation. Trans. JWRI, 5(2): 35.

29. Masumoto, I., Tamaki, K., and Kutsuna, M. 1972. Hot cracking of austenitic stainless steel weld metal, Trans. JWS, 41(11): 1306.

30. Lippold, J. C. 1982. Weld cracking mechanism in austenitic stainless steels. Trends in Welding Research in the U.S., ASM conference proceedings, Metals Park, Ohio, 209247.

31. G. Pacary, M. Moline, and J. C. Lippold, EWI Research BriefNo. B9008, Edison Welding Institute, (1990) 


\section{Distribution}

US Department of Energy

Albuquerque Operations Office

Attn: J. Claycomb

P.O. Box 5400

Albuquerque, NM 87185-5400

US Department of Energy

Albuquerque Operations Office

Attn: E. Whiteman

P.O. Box 5400

Albuquerque, NM 87185-5400

Honeywell Ind.

Kansas City Division

Attn: R. Hanlin

P.O. Box 419159

Kansas City, MO 64141-6159

Honeywell Ind.

Kansas City Division

Attn: D. Wetzler

P.O. Box 419159

Kansas City, MO 64141-6159

Los Alamos National Laboratories

Attn: J. Straw, G780

P.O. Box 1663

Los Alamos, NM 87545

Los Alamos National Laboratories

Attn: R. Gates, C936

P.O. Box 1663

Los Alamos, NM 87545
Los Alamos National Laboratories

Attn: L. Salazar, NW-SS, F630

P.O. Box 1663

Los Alamos, NM 87545

Los Alamos National Laboratories Attn: J. Kachenko

P.O. Box 1663

Los Alamos, NM 87545

Los Alamos National Laboratories Attn: Doug Katz

P.O. Box 1663

Los Alamos, NM 87545

Los Alamos National Laboratories Attn: John Milewski

P.O. Box 1663

Los Alamos, NM 87545

Savannah River Site

Attn: Scott West

Road 1A

Bldg 773A, Rm D-1153

Aiken. SC 29801

Lockheed Martin Energy Systems

Attn: Tom Mustaleski

PO Box 2009, MS 8096

Oak Ridge, TN

3781-8096 


\section{Distribution (continued)}

$\begin{array}{ll}\text { MS-0319 } & \text { Ken Eras, 2613 } \\ \text { MS-0319 } & \text { Carl Vanecek, 2613 } \\ \text { MS-0328 } & \text { Marty Stevenson, 2612 } \\ \text { MS-0367 } & \text { Mark Smith, 1833 } \\ \text { MS-0367 } & \text { Gerald Knorovsky, 1833 } \\ \text { MS-1435 } & \text { James Jellison } \\ \text { MS-9005 } & \text { Rick Wayne, 2200 } \\ \text { MS-9005 } & \text { E. Cull Jr., 2260 } \\ \text { MS-9007 } & \text { Doug Henson, 8400 } \\ \text { MS-9013 } & \text { Sam Johnson, 2266 } \\ \text { MS-9035 } & \text { Marv. Loll, 2265 } \\ \text { MS-9108 } & \text { M. Hardwick, 8414 } \\ \text { MS-9108 } & \text { L. Hoffa, 8414 } \\ \text { MS-9108 } & \text { Cook Story, 8414 } \\ \text { MS-9108 } & \text { Steve Robinson, 8414 } \\ \text { MS-9133 } & \text { Gordon Gibbs, 8419 } \\ \text { MS-9133 } & \text { Jerry Fordham, 8419-2 } \\ \text { MS-9401 } & \text { Jill Hruby, 8702 } \\ \text { MS-9402 } & \text { Ken Wilson, 8722 } \\ \text { MS-9402 } & \text { Chuck Cadden, 8724 } \\ \text { MS-9402 } & \text { Ben Odegard, 8724 (5) }\end{array}$

MS-9402 Annette Newman, 8724

MS-9402 Brian Somerday, 8724

MS-9402 George Thomas, 8724

MS-9403 Mike Dyer, 8700

MS-9042 W. Kawahara, 8725

MS-9042 Jim Handrock, 8727

MS-9042 Mark Perra, 8728

MS-9404 Neville. Moody, 8725

5 MS-9404 Steve Goods, 8725

10 MS-0367 Charlie Robino, 1833

10 MS-9402 John Brooks, 8724

1 MS-9131 Robert Condouris, 8528

3 MS-9018 Central Technical Files, 8940-2

1 MS 0899 Technical Library, 4916

1 MS 9021 Technical Communications Department, 8528/ Technical Library, MS-0899

1 MS 9021 Technical Communications, 8528 for DOE/OSTI 